\title{
Updated guide for the management of malignant hyperthermia
}

\author{
Sheila Riazi, MSc, MD (i) • Natalia Kraeva, PhD • Philip M. Hopkins, MBBS, MD, FRCA
}

Received: 29 November 2017/Revised: 5 February 2018/Accepted: 10 February 2018/Published online: 29 March 2018

(c) Canadian Anesthesiologists' Society 2018

\begin{abstract}
Purpose This continuing professional development module aims to prepare anesthesiologists for the timely recognition and management of a malignant hyperthermia $(\mathrm{MH})$ reaction, which is crucial for averting its lifethreatening complications and ultimately for the patient's survival.

Principal findings Malignant hyperthermia is a genetic disorder of skeletal muscle cells affecting myoplasmic calcium homeostasis. It can present with nonspecific signs of a hypermetabolic reaction, which can be fatal if treatment, including administration of dantrolene sodium, is not implemented promptly. Rapid evaluation and rejection of alternative diagnoses can lead to a prompt diagnosis and treatment and therefore will significantly reduce the complications, including renal failure, cardiac dysfunction, disseminated intravascular coagulation, and death. After the reaction, patients should be observed for a minimum of $24 \mathrm{hr}$ because of the possibility of recrudescence. As it is a genetic condition, survivors and their family members should be referred to a specialized $\mathrm{MH}$ centre for further testing and counselling.

Conclusions The risk of dying from $\mathrm{MH}$ has increased over the past few years. A knowledgeable anesthesiologist who is diligent and attentive can recognize signs of an
\end{abstract}

S. Riazi, MSc, MD $(\varangle) \cdot$ N. Kraeva, PhD

The Department of Anesthesia, University of Toronto, 323-200

Elizabeth St, Toronto, ON M5G 2C4, Canada

e-mail: sheila.riazi@uhn.ca

P. M. Hopkins, MBBS, MD, FRCA

Department of Anaesthesia, University of Leeds, Leeds, United Kingdom impending $\mathrm{MH}$ reaction and treat promptly to avoid complications of this deadly condition.

\section{Objectives of this Continuing Professional Development module:}

After reading this module, the reader should be able to:

1) Demonstrate an understanding of the etiology, pathophysiology, and genetics of malignant hyperthermia.

2) Define the clinical features of malignant hyperthermia to make a prompt diagnosis.

3) Describe the steps in the treatment of malignant hyperthermia.

4) Calculate the recommended required doses of dantrolene for acute as well as post-crisis management of malignant hyperthermia.

5) Set up the referral of the patient and family members to a malignant hyperthermia specialized centre.

\section{Introduction}

Definition and pathophysiology

Malignant hyperthermia (MH) is a pharmacogenetic disorder of skeletal muscle triggered in susceptible individuals by volatile anesthetics and/or succinylcholine. The underlying mechanism of $\mathrm{MH}$ is disruption of excitation-contraction coupling resulting in enhanced calcium ions, $\mathrm{Ca}^{2+}$, release from the sarcoplasmic reticulum via the $\mathrm{Ca}^{2+}$ release channel of the skeletal 
muscle sarcoplasmic reticulum (RyR1) in response to the triggers. $^{1,2}$ It manifests as a potentially lethal hypermetabolic crisis, which can lead to breakdown of muscle cells, resulting in hyperkalemia, acidosis, increased serum creatine kinase (CK) concentration, and myoglobinuria. ${ }^{3,4}$ Complications of $\mathrm{MH}$ include cardiac arrhythmia and cardiac arrest (from acidosis and hyperkalemia), renal failure, compartment syndrome, disseminated intravascular coagulation (DIC), pulmonary edema, and central nervous system injury. ${ }^{1,4}$

\section{Epidemiology}

Malignant hyperthermia is reported to occur in all racial groups with an estimated incidence of $1 / 15,000$ to $1 / 75,000$ anesthetics. ${ }^{1,5,6}$ The true prevalence of MH susceptibility is underestimated because of incomplete penetrance and variable expression of the $\mathrm{MH}$ susceptibility trait. $\mathrm{MH}$ reactions can present with mild, nonspecific symptoms that go unrecognized; besides, due to incomplete penetrance, MH-susceptible individuals might undergo several uneventful anesthetics (on average three) prior to developing a fulminant $\mathrm{MH}$ reaction. ${ }^{3,7}$ Indeed, the prevalence of the MH genetic trait has been estimated to be between 1:2000 and 1:3000, ${ }^{2,8,9}$ which is considerably greater than the reported incidence of clinical MH episodes.

Variable expression and incomplete penetrance might in part be due to genetic factors. It has been suggested that different $\mathrm{MH}$-causative genetic variants confer different sensitivities to the triggering anesthetic agents; moreover, the clinical risk associated with some $\mathrm{MH}$ causative variants might be influenced by other modifying genetic factors, ${ }^{10,11}$ thus further contributing to the variability in MH clinical presentation.

Variability in $\mathrm{MH}$ expression might also be due to anesthesia-related factors, such as the MH-triggering potency of the inhalation anesthetic used, drug dose, and duration of the anesthesia. ${ }^{12,13}$ Such factors as age and gender can also affect the expression of MH. It has been reported that $\mathrm{MH}$ occurs predominantly in younger patients and that $\mathrm{MH}$ reactions occur twice as often in male than in female patients. ${ }^{3,4}$

Malignant hyperthermia mortality dropped from $80 \%$ to less than 5\% after the introduction of a potent $\mathrm{MH}$ antidote, dantrolene, in the late 1970s. Nevertheless, in the first decade of the $21^{\text {st }}$ century mortality has risen to $14 \%{ }^{14}$ and this may be associated with the increased use of $\mathrm{MH}-$ triggering anesthetics outside conventional hospital settings ${ }^{1}$ and possibly the mistaken belief that $\mathrm{MH}$ was not triggered by modern inhalation anesthetics. Regardless of the cause, the increase in mortality emphasizes the need for anesthesiologists to have a sound understanding of $\mathrm{MH}$, even though it is rare.
Pharmacologic triggers and treatment

All inhalation anesthetics (e.g., halothane, ether, desflurane, sevoflurane, isoflurane) except nitrous oxide are reported as MH triggers., ${ }^{3,12}$ Confirming previous findings, a recent study showed that the depolarizing neuromuscular blocking agent, succinylcholine, is associated with adverse events graded as "very likely" or "almost certainly" MH, even when inhalation anesthetics were not used. ${ }^{3}$ The diagnosis of MH susceptibility in patients who survived a succinylcholine-triggered reaction was confirmed by diagnostic muscle biopsy and genetic testing. These findings underscore the necessity of investigating adverse reactions triggered by succinylcholine without volatile anesthetics and the need to stock dantrolene in any facility that uses succinylcholine even if only for airway rescue.

All anesthetic agents other than volatile anesthetic agents and depolarizing neuromuscular blocking agents are considered safe from an $\mathrm{MH}$ point of view.

Studies in different populations have indicated that early dantrolene administration drastically reduces the incidence of complications. They revealed that the complication rates increase with delay in administration of dantrolene treatment. ${ }^{3,4}$ These observations emphasize the need for early diagnosis, ready access, and rapid administration of dantrolene in anesthetizing locations where either succinylcholine or volatile anesthetic agents are used.

\section{Diagnosis of $\mathrm{MH}$}

Fulminant $\mathrm{MH}$ reactions presenting with a full set of rapidly emerging clinical signs of $\mathrm{MH}$ (hypercarbia, tachycardia, hyperthermia, acidosis, muscle rigidity) are nowadays reported to occur only in a small fraction of $\mathrm{MH}$ cases. ${ }^{3,15}$ In recently reported MH cases, the appearance of the first clinical signs is often delayed and they are more insidious. In many of such cases, retrospectively diagnosed as MH susceptible, the signs can subside after discontinuation of the triggering anesthetic and before dantrolene is administered. ${ }^{3,13,15}$

The insidious presentation pattern of MH is likely due to changes in the practice of anesthesia with the use of less potent volatile anesthetics (i.e., sevoflurane and desflurane as opposed to halothane), availability of modern anesthetic drugs, techniques, and monitors, as well as the limited use of succinylcholine, especially in pediatric anesthesia practice.

The non-specific nature of the clinical signs of $\mathrm{MH}$ and its variable clinical presentation, however, might hamper clinical diagnosis of MH in the operating room and lead to a life-threatening delay in treatment. ${ }^{13,16}$ Even though an MH episode may initially appear innocuous, it can evolve 
into a fulminant, life-threatening crisis. Anesthesiologists should be aware of the early signs of an MH reaction and should discontinue all triggering anesthetics with any inappropriate rise in end-tidal $\mathrm{CO}_{2}$ and heart rate with or without temperature elevation.

The Clinical Grading Scale (CGS) ${ }^{17}$-a set of clinical diagnostic criteria for $\mathrm{MH}$ - has been widely and effectively used to rank adverse reactions to anesthetics from "unlikely MH" to "almost certain MH". Nevertheless, an assigned CGS rank may underestimate the likelihood of MH for "milder" cases, for cases when an MH triggering anesthetic agent was withdrawn early in the reaction, as well as for cases without adequate monitoring. ${ }^{3,18}$

Currently, there are two diagnostic approaches for patients potentially at increased risk of developing an MH reaction. These include molecular genetic testing and the ex vivo muscle contracture testing, i.e., the caffeinehalothane contracture test $(\mathrm{CHCT})^{19}$ in North America and the in vitro contracture test (IVCT) elsewhere. ${ }^{20}$

The contracture test measures the contracture response of excised skeletal muscle strips to caffeine and halothane and is regarded as the "gold standard" diagnostic test for MH susceptibility. The CHCT has a sensitivity of $97 \%$ and a specificity of $78 \%,{ }^{21}$ whereas IVCT has a sensitivity of $100 \%$ and a specificity of $94 \% .^{20}$ The drawbacks of contracture testing are its high cost, invasiveness, and the need for specialized testing centres with trained personnel (at present there are only five MH testing centres in North America).

Genetic testing for MH has been seen as an advanced alternative to $\mathrm{MH}$ biopsy testing. The underlying mechanism of $\mathrm{MH}$ is the disruption of excitationcontraction coupling and dysregulation of skeletal muscle $\mathrm{Ca}^{2+}$ homeostasis. As could be expected, pathogenic variants, associated with MH susceptibility, have been identified in genes encoding essential proteins involved in the skeletal muscle excitation-contraction coupling process. These genes are $R Y R l$, encoding the ryanodine receptor-the $\mathrm{Ca}^{2+}$ release channel of the RyR1, CACNA1S, encoding the alpha-1S subunit of the voltagegated $\mathrm{Ca}^{2+}$ channel $\mathrm{Ca}_{\mathrm{v}} 1.1$, also known as the dihydropyridine receptor, and STAC3, encoding Stac3 protein. The RYRI gene has been established as the major gene for $\mathrm{MH}$ with $\mathrm{MH}$-associated $R Y R I$ variants found in more than half of the MH families from different populations around the world. A small number of $\mathrm{MH}-$ susceptible families carry variants in the second $\mathrm{MH}$ gene, CACNA1S. A homozygous STAC3 mutation has been linked to Native American myopathy and $\mathrm{MH}$ susceptibility in one Native American family. ${ }^{1,2,22}$

The discovery of genes associated with MH (RYRl, $C A C N A 1 S$, and STAC3) and availability of the next- generation sequencing technology have allowed fast and cost-efficient screening of large cohorts of MH patients for $\mathrm{MH}$-associated variants and made $\mathrm{MH}$ genetic testing a viable diagnostic approach., ${ }^{2,23}$ Once an $\mathrm{MH}$-causative mutation has been identified in an MH proband, the family members can be screened for this mutation and all the relatives carrying the mutation will be considered $\mathrm{MH}$ susceptible without the need for them to have an invasive muscle biopsy.

Yet, up to $50 \%$ of $\mathrm{MH}$-susceptible individuals do not carry potentially pathogenic variants in the known $\mathrm{MH}-$ associated genes, resulting in a rather low sensitivity of MH genetic testing. ${ }^{2,23}$

At present, the finding of rare variants in RYRl, CACNA1S, and STAC3 also has a low specificity: while there are reports of more than $200 R Y R l$ variants found in association with $\mathrm{MH}$, only $42 R Y R I$ and 2 CACNAIS variants are accepted as $\mathrm{MH}$ causative (www.emhg.org) and can be used in diagnostic genetic testing for MH. It is important to note that until the MH-causative nature of newly identified RYRl variants has been validated by additional studies, individuals carrying such variants should be considered at risk of developing $\mathrm{MH}$ and offered contracture testing to ascertain their MH status.

In summary, due to the complex nature of $\mathrm{MH}$, a negative genetic test result cannot be used to rule out a patient's MH susceptibility; patients with negative genetic results should be offered contracture testing to confirm their MH-negative status.

\section{Malignant hyperthermia and related disorders}

Several skeletal muscle conditions and congenital myopathies have been reported to be associated with MH. Potentially pathogenic variants in $R Y R I$ have been identified in patients with central core disease, multiminicore disease, congenital myopathy with central or internalized nuclei, congenital fibre-type disproportion, King-Denborough syndrome, benign Samaritan congenital myopathy, atypical periodic paralysis, statin myopathies, and heat/exercise-induced exertional rhabdomyolysis. ${ }^{2,24}$ The extent of the overlap between $\mathrm{MH}$ and $R Y R I$-related myopathies remains vague, and counselling of myopathic patients carrying RYRlvariants regarding their $\mathrm{MH}$ susceptibility should be based on integration of clinical, histopathologic, in vitro contracture testing and genetic findings. While their MH status remains unresolved, patients with myopathies carrying a pathogenic variant or a variant of unknown significance in $R Y R 1, C A C N A 1 S$, or $S T A C 3$ should receive trigger-free anesthetics and should be referred to a specialized $\mathrm{MH}$ centre for assessment of their $\mathrm{MH}$ risk and advice on further investigation. ${ }^{25-27}$ 
Differential diagnoses

Clinical signs of $\mathrm{MH}$, such as masseter muscle rigidity (MMR), elevated $\mathrm{CO}_{2}$ production, tachycardia, and fever, are non-specific and can be caused by some other conditions. Thus, about $50 \%$ of patients who developed MMR with triggering anesthetics were diagnosed as $\mathrm{MH}$ negative by subsequent testing ${ }^{7,28}$; increase in $\mathrm{CO}_{2}$ can result from hypoventilation or laparoscopic surgery; rise in body temperature can be caused by, among other factors, sepsis or iatrogenic overheating. Other hypermetabolic conditions that might have similar symptoms but that are not associated with $\mathrm{MH}$ include thyrotoxicosis, pheochromocytoma, neuroleptic malignant syndrome, serotonin syndrome, and intoxication (e.g., cocaine, and ecstasy). $1,16,29$

\section{Diagnosis and treatment of an acute MH reaction}

Common signs of an $\mathrm{MH}$ reaction and complications

Malignant hyperthermia can occur at any time during anesthesia or in the early postoperative period., ${ }^{3,4}$ The progression of the syndrome may be rapid and dramatic or less evident, becoming manifest only after several hours of anesthesia. $^{1,16}$ Early recognition of an impending $\mathrm{MH}$ crisis is crucial for the start of appropriate treatment and ultimately for the patient's survival.

Common signs of $\mathrm{MH}$ reactions are hypercarbia, tachypnea, tachycardia, cardiac arrhythmias, rigidity, cyanosis, unstable blood pressure, hyperthermia, respiratory and metabolic acidosis, and myoglobinuria, with the most frequent initial signs being masseter muscle rigidity (following succinylcholine), hypercarbia, tachycardia, and hyperthermia. ${ }^{3}$

Anesthesiologists should be able to recognize the initial signs of $\mathrm{MH}$ :

1) Masseter muscle rigidity and/or generalized rigidity following succinylcholine administration.

2) Inappropriate hypercapnia, despite increased minute ventilation, or tachypnea when a patient is breathing spontaneously, and also an increase in arterial partial pressure of $\mathrm{CO}_{2}$ on the arterial blood test to more than $60 \mathrm{mmHg}$. The rise in $\mathrm{CO}_{2}$ can be rather gradual and can be masked by repeated increases in minute ventilation. $^{1}$

3) Sinus tachycardia, followed in more than $80 \%$ of $\mathrm{MH}$ reactions by cardiac arrhythmias and unstable blood pressure. This sign can be misinterpreted as inadequate anesthesia and often only retrospectively is recognized as a sign of MH. ${ }^{15}$ Tachycardia can be obtunded in patients receiving beta blockers or remifentanil.

4) Body temperature elevation can be the first to the third reported sign in $63.5 \%$ of $\mathrm{MH}$ reactions indicating the importance of body temperature monitoring. ${ }^{18}$ Of diagnostic importance is not the peak temperature but rather the rate of temperature increase, which can be as high as $1-2^{\circ} \mathrm{C}$ every five minutes. ${ }^{1}$

If not treated, uncontrolled hypermetabolism accompanied by severe hyperthermia (core temperature $>$ $41^{\circ} \mathrm{C}$ ) causes rapid consumption of energy stores and adenosine triphosphate and leads to respiratory and then metabolic acidosis and to a widespread vital organ dysfunction, cerebral edema, and coma. ${ }^{1}$ Breakdown of skeletal muscle, rhabdomyolysis, evidenced by a dramatic increase in serum CK concentration, leads to life-threatening hyperkalemia (severe cardiac arrhythmias and cardiac arrest), myoglobinuria (acute renal failure) manifested by cola-coloured urine, and DIC. The most common complications are reported as renal and cardiac dysfunction. ${ }^{3}$

The Malignant Hyperthermia Association of the United States (MHAUS) offers $\mathrm{MH}$ procedure manuals and education manuals for hospitals, ambulatory surgery centres, and office-based surgery facilities (www.mhaus.org).

\section{Treatment of an acute $\mathrm{MH}$ reaction}

Treatment should be aimed at prompt administration of dantrolene, cooling to a target core temperature of no more than $38.5^{\circ} \mathrm{C}$, hyperventilation, and supportive measures.

1) At the first suspicion of an $\mathrm{MH}$ event, discontinue triggers (volatile inhalation anesthetics and succinylcholine). Disconnect the vaporizer. If the surgery cannot be stopped, the anesthetic should be converted to trigger free, using a total intravenous anesthesia technique.

2) Declare an emergency and call for help-more personnel are needed to avoid delays in treatment and development of complications. Bring in the $\mathrm{MH}$ cart.

3) To bring end-tidal $\mathrm{CO}_{2}$ to normal values, hyperventilate with $100 \%$ oxygen at high gas flows of at least $10 \mathrm{~L} \cdot \mathrm{min}^{-.1}$ Activated charcoal filters can be inserted into the inspiratory and expiratory limbs of the breathing circuit to promptly reduce the anesthetic concentration to minimal levels. Otherwise, a clean circuit can be used if there are sufficient personnel not to delay other treatment priorities.

4) Give $2.5 \mathrm{mg} \cdot \mathrm{kg}^{-1}$ of dantrolene sodium. Rapidly administer the initial bolus intravenously and continue to administer dantrolene every five to ten minutes until 
signs of MH (hypercarbia, rigidity, tachycardia, and high temperature) are controlled and the cardiac and respiratory systems are stabilized. Dantrolene should be started at $2.5 \mathrm{mg} \cdot \mathrm{kg}^{-1}$ and, if there is any response, should be continued at that dose until the hypermetabolism has been corrected. Increasing doses of dantrolene can be administered if there is no sign of response. A ceiling dose of $10 \mathrm{mg} \cdot \mathrm{kg}^{-1}$ is recommended if there is absolutely no effect with lower dose boluses of dantrolene. Note that if, after administering $10 \mathrm{mg} \cdot \mathrm{kg}^{-1}$ of dantrolene, the high temperature, muscle rigidity, and acidosis are not resolving, the differential diagnoses should be reevaluated. If $\mathrm{MH}$ is still considered the likely diagnosis, give further increments of dantrolene, although dantrolene may not be effective with severe muscle necrosis and greater emphasis should be placed on physical body cooling (see below). Each vial of dantrolene sodium contains $20 \mathrm{mg}$ dantrolene and $3 \mathrm{~g}$ mannitol. One vial should be mixed with $60 \mathrm{~mL}$ sterile water for injection. At least 12 bottles of dantrolene for a patient with a weight of $80 \mathrm{~kg}$ should be immediately available for the adequate initial treatment of $2.5 \mathrm{mg} \cdot \mathrm{kg}^{-1}$ dantrolene; at least 36 vials may be needed for the treatment of an adult patient. A more concentrated form of dantrolene sodium, Ryanodex, contains $250 \mathrm{mg}$ in each vial, requiring $5 \mathrm{~mL}$ of sterile water to solubilize. Nevertheless, this preparation is not available in Canada yet.

A) Continue routine anesthetic monitoring, including electrocardiogram, non-invasive blood pressure, oxygen saturation, and end-tidal $\mathrm{CO}_{2}\left(\mathrm{ETCO}_{2}\right)$. Start monitoring core temperature if not doing so yet; monitor arterial or (non-tourniqueted) venous blood gases, serum potassium, lactate, CK (CK elevation may not be apparent for several hours), serum and urine myoglobin, urine output, thyroid function, blood cultures, and the coagulation profile; check for signs of compartment syndrome; check the glucose level hourly if insulin is administered.

B) Treat hyperthermia if the temperature is $>39^{\circ} \mathrm{C}$ or rapidly rising: surface cooling with wet, cold sheets, fans, and ice packs placed in the axillae and groin. Administer cool or cold intravenous isotonic crystalloid. Stop cooling once the temperature falls below $38.5^{\circ} \mathrm{C}$.

C) Hyperkalemia should be treated with bicarbonate (in the setting of an acidosis) and/or intravenous glucose and insulin (e.g., ten units regular insulin in $50 \mathrm{~mL} 50 \%$ glucose titrated to the potassium level). Lifethreatening arrhythmias from hyperkalemia should be treated with 10 to $30 \mathrm{mg} \cdot \mathrm{kg}^{-1}$ of intravenous calcium chloride. Arrhythmias will usually respond to treatment of acidosis and hyperkalemia; if they persist, standard anti-arrhythmic agents may be used (e.g., amiodarone, 150-300 mg for an adult). Do not use calcium channel blockers together with dantrolene administration as they can interact to produce fatal hyperkalemia and cardiovascular collapse. Nevertheless, if a patient is chronically taking calcium channel blockers preoperatively and develops an $\mathrm{MH}$ reaction, dantrolene should not be withheld.

D) To prevent acute renal failure, maintain a urine output greater than $2 \mathrm{~mL} \cdot \mathrm{kg}^{-1} \cdot \mathrm{hr}^{-1}$ by hydration and/or administration of mannitol or furosemide. Remember that each vial of dantrolene sodium contains $3 \mathrm{~g}$ of mannitol and that diuretic-induced hypovolemia should be avoided.

In the United States a "hotline" has been established to provide emergency assistance (1-800-644-9737) in the management of $\mathrm{MH}$. This service is also extended to Canadians. The web site of the MHAUS provides helpful resources (www.mhaus.org).

Once the patient becomes hemodynamically stable, he/ she should be transferred to the intensive care unit for at least $24 \mathrm{hr}$. Key indicators of stability include: declining or normal $\mathrm{ETCO}_{2}$; absence of dysrhythmias; resolving hyperthermia and rigidity.

\section{Post-reaction management}

Observe the patient in an intensive care unit for at least 24 hr. Recrudescence of an MH reaction may occur in $25 \%$ of patients $^{30}$ and may require further therapy. It is suggested by the MHAUS to administer bolus doses of dantrolene sodium $1 \mathrm{mg} \cdot \mathrm{kg}^{-1} i v$ every six hours for at least $24 \mathrm{hr}$ or longer as clinically indicated. Dantrolene can be stopped or the interval between doses increased to q8hr or q12hr if the core temperature is $<38^{\circ} \mathrm{C}$, AND CK is declining, AND muscle is not rigid, AND there is no evidence of myoglobinuria, AND there is metabolic stability for $24 \mathrm{hr}$.

Monitor arterial blood gases, serum CK, potassium and calcium, urine and serum myoglobin, and clotting factors every six hours until they return to normal values; treat, if needed. Core temperature should be continuously monitored until stable.

Counsel the patient and family regarding $\mathrm{MH}$ and the possibility of MH susceptibility in other family members. Refer family members to the nearest $\mathrm{MH}$ diagnostic testing centre for testing. Individuals who experienced an $\mathrm{MH}$ episode should have blood sent for genetic screening of the three implicated genes (www.mhaus.org). 
All departments of anesthesia should have a policy and procedures manual for the treatment of an $\mathrm{MH}$ reaction as well as the anesthetic management of an at-risk individual that includes machine preparation. The responsibilities of health care facilities are stated in the Canadian Guidelines to the Practice of Anesthesia. ${ }^{31}$ Detailed task cards, a management poster, and other cognitive aids and educational material should be freely available. ${ }^{1}$

\section{Management of known or at-risk MH-susceptible patients}

1) Preoperative period: Prepare a clean, vapour-free anesthetic machine, according to the manufacturers' guidelines. Remove succinylcholine vials and vaporizers from the operating room. Activated charcoal filters can be used to expedite preparation of the anesthetic machine. Specific mention of patient's MH susceptibility during the preoperative time out is recommended.

2) Intraoperative period: Standard monitoring as well as continuous core temperature monitoring should be used.

3) Postoperative period: There is no need for extended stay of MH-susceptible patients in the recovery room or in hospital as there is no risk of $\mathrm{MH}$ reaction if these patients are given trigger-free anesthetics. ${ }^{32}$

\section{Clinical case scenario}

A 14-yr-old girl (weight: $50 \mathrm{~kg}$ ) is booked for a laparoscopic appendectomy. She is otherwise healthy with normal developmental milestones. She does not take medication routinely. She had one uneventful anesthetic for tonsillectomy. There is no family history of any anesthetic reaction. Her preoperative blood pressure is $120 / 87 \mathrm{mmHg}$, heart rate is $100 / \mathrm{min}$ (sinus rhythm), and temperature is $36.8^{\circ} \mathrm{C}$. A rapid sequence induction is performed with 100 $\mu \mathrm{g}$ fentanyl, $200 \mathrm{mg}$ propofol, and $50 \mathrm{mg}$ succinylcholine. Initially, the anesthesiologist was not able to open the mouth because of the jaw rigidity, but within a couple of minutes he intubated her with some difficulty.

\section{Instructions for completing the Continuing Professional Development (CPD) module:}

1. Read the current article and the references indicated in bold. Go to: http://www.cas.ca/Members/CPD-Online and select the current module: Updated guide for the management of malignant hyperthermia.

2. Answer the multiple-choice questions regarding the case scenario.

3. Once you have entered all of your answers, you will have access to experts' explanations for all the possible choices.

4. Participants may claim up to four hours of CPD under Section 3 of the CPD program of the Royal College of Physicians and Surgeons of Canada.

\section{Mise à jour sur la gestion de l'hyperthermie maligne}

Résumé

Objectif $\mathrm{Ce}$ module de développement professionnel continu vise à préparer les anesthésiologistes à identifier et gérer en temps opportun une réaction d'hyperthermie maligne (HM), afin d'éviter les complications mettant en danger la vie des patients.

Constatations principales L'hyperthermie maligne est un trouble génétique des cellules musculaires squelettiques affectant l'homéostasie du calcium myoplasmique. Elle peut se traduire par des signes non spécifiques de réaction hypermétabolique, potentiellement fatale si le traitement incluant l'administration de dantrolène sodique n'est pas instauré rapidement. Une évaluation rapide et l'élimination des diagnostics différentiels peuvent permettre un diagnostic et un traitement rapides qui réduiront significativement les complications, notamment l'insuffisance rénale, la dysfonction cardiaque, la coagulation intravasculaire disséminée et le décès. Après la réaction, les patients doivent être maintenus en observation pendant au moins 24 heures en raison d'une recrudescence possible. Puisqu'il s'agit d'un trouble génétique, les survivants et les membres de leurs familles doivent être référés à un centre spécialisé de l'HM pour des tests et conseils supplémentaires.

Conclusions Le risque de décès liés à l'HM a augmenté au cours de ces dernières années. Un anesthésiologiste compétent, faisant preuve de diligence et attentif, peut identifier les signes d'une réaction d'HM imminente et traiter sans retard pour éviter les complications de ce trouble mortel. 
Objectifs de ce module de développement professionnel continu :

Après avoir lu ce module, le lecteur devrait être capable de :

1) Démontrer une connaissance de l'étiologie, de la physiopathologie et de la génétique de l'hyperthermie maligne.

2) Définir les caractéristiques cliniques de l'hyperthermie maligne pour poser un diagnostic rapide.

3) Décrire les étapes du traitement de l'hyperthermie maligne.

4) Calculer les doses requises recommandées de dantrolène pour la gestion aiguë et post crise de l'hyperthermie maligne.

5) Organiser un suivi approprié auprès d'un centre spécialisé de l'hyperthermie maligne pour le patient et les membres de sa famille.

\section{Introduction}

Définition et physiopathologie

L'hyperthermie maligne (HM) est un trouble pharmacogénétique du muscle squelettique déclenché, chez les sujets sensibles, par les anesthésiques volatils et/ ou la succinylcholine. Le mécanisme sous-jacent de l'HM est la perturbation du couplage excitation-contraction entraînant une facilitation de la libération des ions calcium $\mathrm{Ca}^{2+}$ par le réticulum sarcoplasmique, via les canaux de libération du $\mathrm{Ca}^{2+}$ du réticulum sarcoplasmique des muscles squelettiques (RyR1) en réponse aux facteurs déclenchants. $^{1,2}$ Cela se traduit par une crise hypermétabolique potentiellement mortelle qui peut aboutir à la destruction des cellules musculaires, entraînant hyperkaliémie, acidose, élévation de la concentration de créatine kinase (CK) sérique et myoglobinurie. $^{3,4}$ Les complications de l'HM sont notamment: une arythmie cardiaque et un arrêt cardiaque (dus à l'acidose et l'hyperkaliémie), une insuffisance rénale, un syndrome de loge, une coagulation intravasculaire disséminée (CIVD), un œdème pulmonaire et des lésions du système nerveux central. ${ }^{1,4}$

\section{Épidémiologie}

L'hyperthermie maligne a été décrite dans tous les groupes ethniques avec une incidence estimée entre $1 / 15000$ et $1 /$ 75000 anesthésies. $^{1,5,6}$ La prévalence réelle de la sensibilité à l'HM est sous-estimée en raison d'une pénétrance incomplète et d'une expression variable de la prédisposition à l'HM. Les réactions d'HM peuvent donner des symptômes discrets, non spécifiques, passant inaperçus; de plus, en raison de la pénétrance incomplète, les sujets susceptibles à l'HM peuvent subir plusieurs anesthésies qui se dérouleront sans incident particulier (en moyenne trois) avant de présenter une réaction d'HM fulminante. ${ }^{3,7}$ En fait, l'estimation de la prévalence de la susceptibilité génétique à l'HM se situe entre 1/2000 et 1/ $3000,{ }^{2,8,9}$ ce qui est considérablement plus élevé que l'incidence décrite pour les épisodes cliniques d'HM.

L'expression variable et la pénétrance incomplète pourraient être en partie dues à des facteurs génétiques. Des auteurs ont suggéré que différents variants génétiques responsables de l'HM confèrent des sensibilités différentes aux agents anesthésiques déclencheurs; en outre, le risque clinique associé à certains variants responsables de 1'HM pourrait être influencé par d'autres facteurs modificateurs génétiques, ${ }^{10,11}$ contribuant ainsi davantage à la variabilité du tableau clinique de l'HM.

La variabilité de l'expression de l'HM pourrait aussi être due à des facteurs liés à l'anesthésie, tels que la puissance de déclenchement de l'anesthésique inhalé utilisé, de la dose de médicament et de la durée de l'anesthésie. ${ }^{12,13}$ Des facteurs tels que l'âge et le sexe peuvent également jouer sur l'expression de l'HM. La survenue d'une HM a surtout été décrite chez des patients plus jeunes avec des réactions survenant deux fois plus souvent chez les hommes que chez les femmes. 3,4

La mortalité due à l'hyperthermie maligne est passée de $80 \%$ à moins de $5 \%$ depuis l'introduction d'un puissant antidote de l'HM à la fin des années 1970 : le dantrolène. Cependant, la mortalité a augmenté de nouveau à $14 \%$ dans la première décennie du $\mathrm{XXI}^{\mathrm{e}}$ siècle, ${ }^{14}$ et cela est peut-être associé à une plus grande utilisation d'anesthésiques déclencheurs d'HM en dehors des cadres hospitaliers conventionnels ${ }^{1}$ et possiblement aussi à la fausse impression que l'HM n'est pas déclenchée par les anesthésiques inhalés modernes. Indépendamment de la cause, l'augmentation de la mortalité souligne le besoin d'une connaissance approfondie de l'HM par les anesthésistes, même s'il s'agit d'un événement rare.

Déclencheurs pharmacologiques et traitement

Tous les anesthésiques inhalés (par exemple enflurane, éther, desflurane, sévoflurane, isoflurane) à l'exception du protoxyde d'azote, sont décrits comme des déclencheurs d'HM. ${ }^{3,12}$ Confirmant des constatations antérieures, une étude récente a montré que les curares dépolarisants, tels que la succinylcholine, sont associés à des événements indésirables classés «HM très probable » ou « HM presque certaine », même sans l'utilisation d'agents anesthésiques inhalés. ${ }^{3}$ Le diagnostic de susceptibilité de 
l'HM chez des patients ayant survécu à une réaction déclenchée par la succinylcholine a été confirmé par une biopsie musculaire et par un test génétique. Ces constatations soulignent la nécessité d'étudier les réactions indésirables déclenchées par la succinylcholine sans anesthésiques volatils et le besoin de conserver du dantrolène dans tout établissement utilisant la succinylcholine, même si ce n'est que dans un but de sauvetage des voies respiratoires.

Tous les autres agents anesthésiques (en dehors des anesthésiques volatils et des curares dépolarisants) sont considérés sans danger par rapport à l'HM.

Les études menées chez différentes populations ont indiqué qu'une administration précoce de dantrolène réduit considérablement l'incidence des complications. Elles ont révélé que les taux de complications augmentent avec le retard d'administration du traitement au dantrolène. ${ }^{3,4}$ Ces observations insistent sur la nécessité d'un diagnostic précoce, d'un accès facile et d'une administration rapide de dantrolène partout où une anesthésie par succinylcholine ou agent anesthésique volatil est utilisée.

\section{Diagnostic de l'HM}

Les réactions fulminantes d'HM avec un tableau complet de signes cliniques d'apparition rapide (hypercapnie, tachycardie, hyperthermie, acidose, rigidité musculaire) ne sont maintenant décrites que dans une petite fraction des cas d'HM. ${ }^{3,15}$ Dans les cas d'HM récemment publiés, les premiers signes cliniques apparaissent souvent avec retard et sont plus insidieux. Dans de tels cas, au diagnostic rétrospectif de susceptibilité à l'HM, les signes peuvent disparaître après l'interruption de l'anesthésique déclencheur et avant l'administration de dantrolène. ${ }^{3,13,15}$

Ce tableau clinique insidieux de l'HM est probablement dû aux modifications de la pratique de l'anesthésie avec l'utilisation d'anesthésiques volatils moins puissants (par ex. sévoflurane et desflurane par opposition à l'halothane), la disponibilité de médicaments, de techniques et de moniteurs anesthésiques modernes, ainsi qu'un recours limité à la succinylcholine, notamment pour l'anesthésie pédiatrique.

Le caractère non spécifique des signes cliniques de l'HM et la variabilité de ses formes cliniques peuvent toutefois retarder le diagnostic clinique en salle d'opération et entraîner un retard de traitement mettant en jeu la vie du patient.$^{13,16}$ Même si un épisode d'HM peut paraitre initialement inoffensif, il peut évoluer en crise fulminante menaçant le pronostic vital. Les anesthésiologistes doivent connaître les signes précoces d'une réaction d'HM et arrêter tous les anesthésiques déclencheurs avec une élévation inopportune du $\mathrm{CO}_{2}$ en fin d'expiration et de la fréquence cardiaque, avec ou sans élévation de la température corporelle.

L'échelle de cotation clinique Clinical Grading Scale $(\mathrm{CGS})^{17}$ - un ensemble de critères cliniques diagnostiques de l'HM - a été largement et efficacement utilisée pour classer les réactions indésirables aux anesthésiques, de « $\mathrm{HM}$ improbable » à «HM presque certaine». Néanmoins, l'attribution d'un classement CGS peut sous-estimer la probabilité de l'HM dans les cas «plus légers », au cours desquels un anesthésique déclenchant une $\mathrm{HM}$ a été arrêté précocement dans la réaction ainsi que dans les cas sans surveillance adéquate. ${ }^{3,18}$

Il y a actuellement deux approches diagnostiques pour les patients potentiellement à plus grand risque de présenter une réaction d'HM. Il s'agit notamment d'un test de génétique moléculaire et du test de contracture musculaire ex vivo, c'est-à-dire, le test de contracture à la caféine-halothane $(\mathrm{CHCT})^{19}$ en Amérique du Nord et le test de contracture in vitro (IVCT) ailleurs. ${ }^{20}$

Le test de contracture mesure la réponse à la caféine et à l'halothane de bandes de muscles squelettiques excisés; on le considère comme le «test diagnostique de référence » ( « gold standard») de la susceptibilité à l'HM. Le CHCT a une sensibilité de $97 \%$ et une spécificité de $78 \%{ }^{21}$ tandis que l'IVCT a une sensibilité de $100 \%$ et une spécificité de $94 \% .^{20}$ Les inconvénients du test de contracture sont son coût élevé, son caractère invasif et le besoin de faire appel à des centres de tests spécialisés avec du personnel entrâné (il n'y a actuellement que cinq centres de tests pour l'HM en Amérique du Nord).

Le test génétique de l'HM a été proposé comme alternative avancée à la biopsie. Le mécanisme sous-jacent de l'HM et la perturbation du couplage excitation-contraction et la dérégulation de l'homéostasie $\mathrm{du} \mathrm{Ca}^{2+}$ dans le muscle squelettique. Comme on pourrait s'y attendre, des variantes pathogéniques associées à la susceptibilité à l'HM ont été identifiées dans des gènes encodant des protéines essentielles impliquées dans le processus de couplage excitationcontraction du muscle squelettique. Ces gènes sont RYRl, codant pour le récepteur de la ryanodine (le canal de libération $\left.\mathrm{du} \mathrm{Ca}^{2+} \mathrm{RyR} 1\right), C A C N A 1 S$ encodant la sous-unité alpha- $1 \mathrm{~S} \mathrm{du}$ canal $\mathrm{Ca}^{2+}$ voltage-dépendant $\mathrm{Ca}_{\mathrm{v}} 1.1$ (également connu comme récepteur de la dihydropyridine) et $S T A C 3$, encodant la protéine $\mathrm{Stac} 3$. Le gène $R Y R I$ est connu pour être le gène principal impliqué dans l'HM avec des variants RYRl associés à l'HM et retrouvés chez plus de la moitié des familles atteintes dans différentes populations autour du monde. Un petit nombre de familles présentant une susceptibilité à l'HM portent des variants du second gène de l'HM, CACNAIS. Une mutation homozygote $S T A C 3$ a été liée à la myopathie des Premières Nations américaines et à la susceptibilité à l'HM dans une famille des Premières Nations. ${ }^{1,2,22}$ 
La découverte de gènes associés à l'HM (RYRI, $C A C N A 1 S$ et $S T A C 3$ ) et la disponibilité des technologies de séquençage de dernier cri ont permis un dépistage rentable sur de grandes cohortes de patients HM, à la recherche de variants associés à l'HM, et ils ont fait du test génétique de l'HM une approche diagnostique viable. ${ }^{2,23}$ Une fois la mutation causale de l'HM identifiée chez un patient, les membres de la famille peuvent faire l'objet d'un dépistage pour cette mutation et tous ceux qui la portent seront considérés comme susceptibles de faire une HM sans qu'il soit nécessaire de pratiquer sur eux une biopsie musculaire invasive.

Cependant, jusqu'à $50 \%$ des sujets ayant une susceptibilité pour l'HM ne sont pas porteurs des variants potentiellement pathogènes connus pour être associés à l'HM, si bien que la sensibilité du test génétique de l'HM est relativement faible., ${ }^{2,23}$

À l'heure actuelle, la découverte de variants rares de RYRI, CACNA1S, et STAC3 a aussi une faible spécificité : bien qu'on ait décrit plus de 200 variants de $R Y R I$ associés à l'HM, seulement 42 variants de RYRl et 2 de CACNAIS ont été reconnus responsables d'HM (www.emhg.org) et peuvent être utilisés dans le test génétique diagnostique de l'HM. Il est important de noter que jusqu'à ce que le caractère causal d'un variant nouvellement identifié de RYRl ait été validé par des études supplémentaires, les sujets porteurs de tels variants doivent être considérés à risque de développer une $\mathrm{HM}$ et on doit leur proposer un test de contracture pour vérifier leur statut.

En résumé, compte tenu de la nature complexe de l'HM, un résultat de test génétique négatif ne peut pas servir à éliminer la susceptibilité à l'HM d'un patient; il faut proposer un test de contracture aux patients dont les résultats génétiques sont négatifs pour confirmer leur statut négatif envers l'HM.

Hyperthermie maligne et troubles apparentés

Plusieurs affections des muscles squelettiques et myopathies congénitales ont été décrites comme étant associées à l'HM. Des variants potentiellement pathogènes de RYRI ont été identifiés chez des patients ayant une myopathie à «central cores », une myopathie à «multiminicores », une myopathie à «cores centraux» ou internalisés, une myopathie congénitale avec disproportion des types de fibres, un syndrome de King-Denborough, une myopathie congénitale bénigne des Samaritains, une paralysie périodique atypique, les myopathies dues aux statines, la rhabdomyolyse d'épuisement induite par la chaleur/l'activité physique. ${ }^{2,24}$ L'ampleur du chevauchement entre l'HM et les myopathies liées à $R Y R I$-reste vague et le soutien psychologique des patients porteurs de variants de RYRI concernant leur susceptibilité à l'HM doit reposer sur une vue d'ensemble des constatations cliniques, histopathologiques, génétiques, et des résultats des tests de contracture in vitro. Tandis que leur statut envers l'HM reste indéterminé, les patients présentant une myopathie et porteurs d'un variant pathogène de signification inconnue sur RYRl, CACNAIS ou STAC3 doivent recevoir des anesthésiques non déclencheurs et doivent être orientés sur des centres spécialisés de l'HM pour une évaluation de leur risque et des conseils sur des compléments d'investigation. ${ }^{25-27}$

\section{Diagnostics différentiels}

Les signes cliniques de l'HM, tels que la rigidité du masséter (RM), l'augmentation de production de $\mathrm{CO}_{2}$, la tachycardie et la fièvre ne sont pas spécifiques et peuvent avoir d'autres causes. Ainsi, environ $50 \%$ des patients ayant présenté une RM avec des anesthésiques déclencheurs ont reçu un diagnostic négatif d'HM aux tests ultérieurs ${ }^{7,28}$; l'augmentation du $\mathrm{CO}_{2}$ peut résulter d'une hypoventilation ou d'une chirurgie laparoscopique; l'élévation de la température corporelle peut être causée, notamment, par un sepsis ou un réchauffement iatrogène excessif. D'autres troubles hypermétaboliques ayant des symptômes semblables, mais n'étant pas associés à l'HM, sont la thyréotoxicose, le phéochromocytome, le syndrome malin des neuroleptiques, le syndrome sérotoninergique et certaines intoxications (par exemple à la cocaïne ou à l'ecstasy). ${ }^{1,16,29}$

\section{Diagnostic et traitement d'une réaction aiguë d'HM}

Signes fréquents et complications d'une réaction d'HM

Une hyperthermie maligne peut survenir à tout moment au cours d'une anesthésie ou pendant la période postopératoire initiale. ${ }^{3,4}$ L'évolution du syndrome peut être rapide et dramatique ou moins évidente, ne se manifestant qu'après plusieurs heures d'anesthésie. ${ }^{1,16}$ L'identification précoce d'une crise d'HM imminente est cruciale pour l'instauration d'un traitement adapté et pour la survie du patient.

Les signes fréquents de réaction d'HM sont les suivants : hypercapnie, tachypnée, tachycardie, troubles du rythme cardiaque, rigidité, cyanose, pression artérielle instable, hyperthermie, acidose respiratoire et métabolique et myoglobinurie; les signes initiaux les plus fréquents sont la rigidité du masséter (après succinylcholine), l'hypercapnie, la tachycardie, et l'hyperthermie. ${ }^{3}$ 
Les anesthésiologistes doivent pouvoir identifier les signes initiaux de l'HM :

1) Rigidité du masséter et/ou rigidité généralisée après administration de succinylcholine.

2) Une hypercapnie inappropriée, malgré une augmentation de la ventilation minute, ou une tachypnée alors que le patient respire spontanément, et aussi une augmentation de la pression partielle de $\mathrm{CO}_{2}$ dans le sang artériel, supérieure à $60 \mathrm{mmHg}$. L'augmentation du $\mathrm{CO}_{2}$ peut être plutôt progressive et masquée par les augmentations répétées de la ventilation minute. ${ }^{1}$

3) La tachycardie sinusale, suivie dans plus de $80 \%$ des réactions d'HM d'arythmie cardiaque et d'instabilité de la pression artérielle. Ce signe peut être mal interprété et faire évoquer une anesthésie insuffisante; il n'est souvent reconnu comme signe d'HM que de façon rétrospective. ${ }^{15}$ La tachycardie peut être masquée chez les patients recevant des bêta bloqueurs ou du rémifentanil.

4) L'élévation de la température corporelle peut être le premier ou l'un des trois premiers signes signalés dans 63,5\% des réactions d'HM, soulignant l'importance de la surveillance de la température corporelle. ${ }^{18}$ Sur le plan diagnostique, ce qui importe n'est pas la température maximale, mais plutôt la vitesse de son augmentation qui peut atteindre 1 à $2{ }^{\circ} \mathrm{C}$ par période de cinq minutes. ${ }^{1}$

S'il n'est pas traité, un hypermétabolisme non contrôlé accompagné d'hyperthermie sévère (température centrale $>41{ }^{\circ} \mathrm{C}$ ) entraîne une consommation rapide des réserves énergétiques et d'adénosine triphosphate, aboutissant à une acidose respiratoire, puis métabolique et à dysfonctionnement étendu des organes vitaux, un œdème cérébral et un coma. ${ }^{1}$ La désintégration des muscles squelettiques, la rhabdomyolyse, mise en évidence par une augmentation impressionnante de la concentration sérique de $\mathrm{CK}$, conduit à une hyperkaliémie potentiellement mortelle (troubles du rythme cardiaque sévères et arrêt cardiaque), une myoglobinurie (insuffisance rénale aiguë) se traduisant par des urines de couleur très foncée (cola) et une CIVD. Les complications le plus souvent signalées sont les dysfonctionnements rénaux et cardiaques. ${ }^{3}$

L'association américaine de l'hyperthermie maligne (MHAUS - Malignant Hyperthermia Association of the United States) propose des manuels de procédures et des manuels éducatifs sur l'HM aux hôpitaux, centres de chirurgie ambulatoires et aux cliniques pratiquant des chirurgies (www.mhaus.org).
Traitement d'une réaction aiguë d'HM

Le traitement doit viser une administration rapide de dantrolène, le refroidissement jusqu'à une température centrale cible ne dépassant pas $38,5^{\circ} \mathrm{C}$, une hyperventilation et des mesures de soutien.

1) Au premier soupçon d'HM, arrêter l'administration de déclencheurs (anesthésiques volatils inhalés et succinylcholine). Débrancher le vaporisateur. Si la chirurgie ne peut pas être arrêtée, l'anesthésie doit être convertie en anesthésie sans déclencheur, utilisant uniquement une technique par voie intraveineuse.

2) Déclarer une situation d'urgence et demander de l'aide : davantage de personnel est nécessaire pour éviter les retards dans le traitement et la survenue de complications. Faire venir le chariot d'HM.

3) Pour ramener le $\mathrm{CO}_{2}$ en fin d'expiration à des valeurs normales, hyperventiler à l'oxygène pur à haut débit (au moins $10 \mathrm{~L} \cdot \min ^{-1}$ ). Des filtres à charbon activé peuvent être insérés dans les bras inspiratoire et expiratoire du circuit respiratoire pour abaisser rapidement la concentration de l'anesthésique à des niveaux minimums. Sinon, un circuit propre peut être utilisé s'il y a suffisamment de personnel afin de ne pas retarder d'autres priorités thérapeutiques.

4) Administrer $2,5 \mathrm{mg} \cdot \mathrm{kg}^{-1}$ de dantrolène sodique. Administrer rapidement le bolus initial par voie intraveineuse et continuer d'administrer du dantrolène toutes les 5 à 10 minutes jusqu'à ce que les signes d'HM (hypercapnie, rigidité, tachycardie et température élevée) soient contrôlés et que les systèmes cardiaque et respiratoire soient stabilisés. Le dantrolène doit être débuté à la dose de $2,5 \mathrm{mg} \cdot \mathrm{kg}^{-1}$ et, s'il y a une réponse, être poursuivi à la même dose jusqu'à la correction de l'hypermétabolisme. Des doses croissantes de dantrolène peuvent être administrées en l'absence de réponse. Une dose maximum de $10 \mathrm{mg} \cdot \mathrm{kg}^{-1}$ est recommandée si des bolus de doses moindres de dantrolène n'ont absolument aucun effet. Notez que si, après avoir administré $10 \mathrm{mg} \cdot \mathrm{kg}^{-1}$ de dantrolène, la température élevée, la rigidité musculaire et l'acidose n'ont pas cédé, le diagnostic différentiel doit être réévalué. Si l'HM reste le diagnostic vraisemblable, continuer à augmenter la dose de dantrolène, bien que ce dernier puisse ne pas être efficace en cas de nécrose musculaire sévère; il y a alors lieu d'insister davantage sur le refroidissement du corps (voir ci-dessous). Chaque flacon de dantrolène sodique contient $20 \mathrm{mg}$ de dantrolène et $3 \mathrm{~g}$ de mannitol. Le contenu d'un 
flacon doit être mélangé à $60 \mathrm{~mL}$ d'eau pour préparation injectable. Il faut disposer immédiatement d'au moins 12 flacons de dantrolène pour un patient pesant $80 \mathrm{~kg}$ afin d'instaurer le traitement initial adéquat à la dose de $2,5 \mathrm{mg} \cdot \mathrm{kg}^{-1}$; un minimum de 36 flacons peut être nécessaire pour le traitement d'un patient adulte. Une forme plus concentrée de dantrolène sodique, Ryanodex, contient $250 \mathrm{mg}$ par flacon, qui peuvent être dissous dans $5 \mathrm{~mL}$ d'eau stérile pour injection. Néanmoins, cette préparation n'est pas encore disponible au Canada.

A. Continuer la surveillance habituelle de l'anesthésie, incluant électrocardiogramme, pression artérielle non invasive, saturation en oxygène et $\mathrm{CO}_{2}$ en fin d'expiration $\left(\mathrm{ETCO}_{2}\right)$. Commencer la surveillance de la température centrale si ce n'est pas déjà fait; surveiller les gaz artériel et veineux (sans garrot), le potassium sérique, les lactates, la CK (une élévation de la CK peut ne pas apparaître avant plusieurs heures, la myoglobine sérique et urinaire, le débit urinaire, la fonction thyroïdienne, les cultures sanguines et le profil de coagulation; rechercher les signes d'un syndrome de loge; vérifier la glycémie toutes les heures en cas d'administration d'insuline.

B. Traiter l'hyperthermie si la température est $>39{ }^{\circ} \mathrm{C}$ ou monte rapidement : refroidissement de surface avec des linges humides et froids et des blocs refroidissants (glacés) sur les aisselles et dans l'aine. Administrer des solutions cristalloïdes isotoniques fraîches ou froides par voie intraveineuse. Cesser de refroidir lorsque la température redescend en dessous de $38,5^{\circ} \mathrm{C}$.

C. L'hyperkaliémie doit être traitée avec du bicarbonate (dans le cadre d'une acidose) et/ou du glucose et de l'insuline par voie intraveineuse (par ex. dix unités d'insuline standard dans $50 \mathrm{~mL}$ de glucose à $50 \%$ titrés selon le taux de potassium). Les troubles du rythme mettant la vie en danger à cause de l'hyperkaliémie doivent être traités avec 10 à $30 \mathrm{mg} \cdot \mathrm{kg}^{-1}$ de chlorure de calcium par voie intraveineuse. Les troubles du rythme répondent habituellement au traitement de l'acidose et de l'hyperkaliémie; s'ils persistent, des agents antiarythmique usuels peuvent être utilisés (par ex., amiodarone, 150 à $300 \mathrm{mg}$ pour un adulte). Ne pas utiliser de bloqueurs des canaux calcium conjointement avec l'administration de dantrolène, car ils peuvent interagir et provoquer une hyperkaliémie fatale avec collapsus cardiovasculaire. Néanmoins, si un patient reçoit régulièrement un bloqueur des canaux calciques en préopératoire et développe une réaction d'HM, le dantrolène ne doit pas être suspendu.

D. Pour éviter l'insuffisance rénale aiguë, maintenir un débit urinaire supérieur à $2 \mathrm{~mL} \cdot \mathrm{kg}^{-1} \cdot \mathrm{h}^{-1}$ grâce à l'hydratation et/ou l'administration de mannitol ou de furosémide. Ne pas oublier que chaque flacon de dantrolène sodique contient $3 \mathrm{~g}$ de mannitol et qu'il faut éviter une hypovolémie induite par le diurétique.

Une ligne d'aide directe a été mise en place aux États-Unis qui apporte une aide d'urgence (1-800-6449737) pour la gestion de l'HM. Ce service est également étendu aux Canadiens. Le site Web de la MHAUS fournit des ressources utiles (www.mhaus.org).

Lorsque le patient est redevenu stable sur le plan hémodynamique, il/elle doit être transféré(e) à l'unité de soins intensifs pendant au moins 24 heures. Les indicateurs clés de la stabilité sont, notamment : $\mathrm{ETCO}_{2}$ en baisse ou normale; absence de trouble du rythme cardiaque; résolution de l'hyperthermie et de la rigidité.

Gestion après la réaction

Observation du patient à l'unité de soins intensifs pendant au moins $24 \mathrm{~h}$. Une recrudescence d'une réaction d'HM peut survenir chez $25 \%$ des patients ${ }^{30}$ et peut nécessiter un traitement supplémentaire. La MHAUS suggère d'administrer des bolus de $1 \mathrm{mg} \cdot \mathrm{kg}^{-1}$ i.v. de dantrolène sodique toutes les six heures pendant au moins 24 heures en fonction des indications cliniques. Le dantrolène peut être arrêté ou l'intervalle entre les doses peut être allongé à toutes les 8 ou 12 heures si la température centrale est $<38{ }^{\circ} \mathrm{C}$ ET si la CK diminue ET en l'absence de rigidité musculaire ET en l'absence de signes de myoglobinurie ET en cas de stabilité métabolique pendant 24 heures.

Surveiller les gaz artériels, la CK, le potassium et le calcium sériques, la myoglobine sérique et urinaire, ainsi que les facteurs de coagulation toutes les six heures jusqu'à ce que ces valeurs reviennent à la normale; traiter, si nécessaire. La température centrale doit être surveillée en permanence jusqu'à ce qu'elle soit stable.

Il faut conseiller le patient et la famille concernant l'HM et la possibilité de susceptibilité d'HM chez d'autres membres de la famille, et orienter les membres de la famille vers le centre de tests diagnostiques de l'HM le plus proche pour des tests. Un échantillon de sang des personnes ayant présenté un épisode d'HM devrait être envoyé pour la recherche des trois gènes impliqués (www.mhaus.org).

Tous les départements d'anesthésie doivent disposer d'une politique et d'un manuel de procédures à suivre pour 
le traitement d'une HM ainsi que la gestion de l'anesthésie chez les patients présentant un risque, ce qui inclut la préparation des machines. Les responsabilités des établissements de soins de santé sont définies dans les lignes directrices canadiennes de pratique de l'anesthésie. ${ }^{31}$ Des cartes de tâches détaillées, une affiche de gestion et d'autres aides cognitives et matériels de formation devraient être facilement disponibles. ${ }^{1}$

Gestion des patients à risque connu ou susceptibles de faire une $\mathrm{HM}$

1) Période préopératoire: préparer une machine d'anesthésie propre, sans agent volatil, conformément aux lignes directrices du fabricant. Retirer les flacons de succinylcholine et les vaporisateurs d'agents anesthésiques volatils de la salle d'opération. Des filtres à charbon activé peuvent être utilisés pour accélérer la préparation de la machine d'anesthésie. Une mention spécifique de la susceptibilité du patient à l'HM pendant la phase préopératoire est recommandée.

2) Période peropératoire : surveillance usuelle et surveillance continue de la température centrale.

3) Période postopératoire : il n'est pas nécessaire de prolonger le séjour des patients susceptibles d'HM dans la salle de réveil ou à l'hôpital, car ces patients ne courent pas de risque de réaction d'HM s'ils ont reçu une anesthésie sans agents déclencheurs. ${ }^{32}$

\section{Scénario de cas clinique}

Une jeune fille âgée de 14 ans (pesant $50 \mathrm{~kg}$ ) doit subir une appendicectomie laparoscopique. Elle est par ailleurs en bonne santé et son développement est tout à fait normal. Elle ne prend aucun médicament de façon régulière. Elle a subi une anesthésie pour amygdalectomie sans problème particulier. Il n'y a pas d'antécédents familiaux de réaction quelconque à un anesthésique. Sa tension artérielle préopératoire est de $120 / 87 \mathrm{mmHg}$ avec une fréquence cardiaque de 100/min (rythme sinusal) et sa température est de $36,8{ }^{\circ} \mathrm{C}$. Une induction à séquence rapide est pratiquée avec $100 \mu \mathrm{g}$ de fentanyl, $200 \mathrm{mg}$ de propofol et $50 \mathrm{mg}$ de succinylcholine. Au début, l'anesthésiologiste ne parvient pas à ouvrir la bouche de la patiente en raison d'une rigidité de la mâchoire, mais il parvient enfin à l'intuber avec quelques difficultés après quelques minutes.
Directives pour compléter le module de développement professionnel continu (DPC) :

1. Lisez l'article actuel ainsi que les références imprimées en gras. Allez à : http://www.cas.ca/ Membres/modules-de-DPC et choisissez le module actuel : Mise à jour du guide pour la gestion de l'hyperthermie maligne.

2. Répondez aux questions à choix multiple concernant le scénario du cas clinique.

3. Après avoir saisi toutes vos réponses, vous aurez accès aux explications des experts concernant tous les choix possibles.

4. Les participants peuvent réclamer jusqu'à quatre heures de DPC au titre de la section 3 du programme de DPC du Collège royal des médecins et chirurgiens du Canada.

Conflicts of interest None declared.

Editorial responsibility This submission was handled by Dr. Stéphane Lambert, CPD Editor, Canadian Journal of Anesthesia.

Funding sources Sheila Riazi is supported by the Merit Award, Department of Anesthesia, University of Toronto.

Conflits d'intérêts Aucun déclaré.

Responsabilité éditoriale Cet article a été traité par Dr A. Stéphane Lambert, rédacteur des DPC, Journal canadien d'anesthésie.

Sources de financement Sheila Riazi est soutenue par un Merit Award, Département d'anesthésie, Université de Toronto.

\section{References}

1. Rosenberg H, Pollock N, Schiemann A, Bulger T, Stowell K. Malignant hyperthermia: a review. Orphanet J Rare Dis 2015; 10: 93 (free access).

2. Riazi S, Kraeva N, Hopkins PM. Malignant hyperthermia in the post-genomics era: new perspectives on an old concept. Anesthesiology 2018; 128: 168-80.

3. Riazi S, Larach MG, Hu C, Wijeysundera D, Massey C, Kraeva $N$. Malignant hyperthermia in Canada: characteristics of index anesthetics in 129 malignant hyperthermia susceptible probands. Anesth Analg 2014; 118: 381-7.

4. Larach MG, Gronert GA, Allen GC, Brandom BW, Lehman EB. Clinical presentation, treatment, and complications of malignant hyperthermia in North America from 1987 to 2006. Anesth Analg 2010; 110: 498-507.

5. Lu Z, Rosenberg $\mathrm{H}, \mathrm{Li}$ G. Prevalence of malignant hyperthermia diagnosis in hospital discharge records in California, Florida, New York, and Wisconsin. J Clin Anesth 2017; 39: 10-4.

6. Ording $H$. Incidence of malignant hyperthermia in Denmark. Anesth Analg 1985; 64: 700-4. 
7. Rosenberg H, Davis M, James D, Pollock N, Stowell K. Malignant hyperthermia. Orphanet J Rare Dis 2007; 2: 21 (free access).

8. Monnier N, Krivosic-Horber R, Payen JF, et al. Presence of two different genetic traits in malignant hyperthermia families: Implication for genetic analysis, diagnosis, and incidence of malignant hyperthermia susceptibility. Anesthesiology 2002; 97 : 1067-74 (free access).

9. Gonsalves $S G, N g D$, Johnston JJ, et al. Using exome data to identify malignant hyperthermia susceptibility mutations. Anesthesiology 2013; 119: 1043-53 (free access).

10. Carpenter D, Robinson RL, Quinnell RJ, et al. Genetic variation in RYR1 and malignant hyperthermia phenotypes. Br J Anaesth 2009; 103: 538-48 (free access).

11. Robinson $R$, Hopkins $P$, Carsana A, et al. Several interacting genes influence the malignant hyperthermia phenotype. Hum Genet 2003; 112: 217-8.

12. Hopkins PM. Malignant hyperthermia: pharmacology of triggering. Br J Anaesth 2011; 107: 48-56 (free access).

13. Heytens $L$, Forget $P$, Scholtes JL, Veyckemans $F$. The changing face of malignant hyperthermia: Less fulminant, more insidious. Anaesth Intensive Care 2015; 43: 506-11 (free access).

14. Rosero EB, Adesanya AO, Timaran CH, Joshi GP. Trends and outcomes of malignant hyperthermia in the United States, 2000 to 2005. Anesthesiology 2009; 110: 89-94 (free access).

15. Schneiderbanger $D$, Johannsen $S$, Roewer $N$, Schuster $F$. Management of malignant hyperthermia: diagnosis and treatment. Ther Clin Risk Manag 2014; 10: 355-62 (free access).

16. Glahn KP, Ellis FR, Halsall PJ, et al. Recognizing and managing a malignant hyperthermia crisis: guidelines from the European Malignant Hyperthermia Group. Br J Anaesth 2010; 105: 417-20 (free access).

17. Larach $M G$, Localio AR, Allen $G C$, et al. A clinical grading scale to predict malignant hyperthermia susceptibility. Anesthesiology 1994; 80: 771-9 (free access).

18. Larach MG, Brandom BW, Allen GC, Gronert GA, Lehman EB. Malignant hyperthermia deaths related to inadequate temperature monitoring, 2007-2012: a report from the North American malignant hyperthermia registry of the Malignant Hyperthermia Association of the United States. Anesth Analg 2014; 119: 135966 (free access).

19. Larach $M G$. Standardization of the caffeine halothane muscle contracture test. North American Malignant Hyperthermia Group. Anesth Analg 1989; 69: 511-5.

20. Hopkins PM, Ruffert H, Snoeck MM, et al. European Malignant Hyperthermia Group guidelines for investigation of malignant hyperthermia susceptibility. Br J Anaesth 2015; 115: 531-9 (free access).

21. Allen GC, Larach $M G$, Kunselman AR. The sensitivity and specificity of the caffeine-halothane contracture test: a report from the North American Malignant Hyperthermia Registry. The North American Malignant Hyperthermia Registry of MHAUS. Anesthesiology 1998; 88: 579-88 (free access).

22. Horstick EJ, Linsley JW, Dowling JJ, et al. Stac 3 is a component of the excitation-contraction coupling machinery and mutated in Native American myopathy. Nat Commun 2013; 4: 1952 (free access).

23. Stowell KM. DNA testing for malignant hyperthermia: the reality and the dream. Anesth Analg 2014; 118: 397-406.

24. Kraeva N, Sapa A, Dowling JJ, Riazi S. Malignant hyperthermia susceptibility in patients with exertional rhabdomyolysis: a retrospective cohort study and updated systematic review. Can J Anesth 2017; 64: 736-43.

25. Riazi S, Kraeva N, Muldoon SM, et al. Malignant hyperthermia and the clinical significance of type-1 ryanodine receptor gene (RYR1) variants: proceedings of the 2013 MHAUS scientific conference. Can J Anesth 2014; 61: 1040-9 (free access).

26. Litman RS, Griggs SM, Dowling JJ, Riazi S. Malignant hyperthermia susceptibility and related diseases. Anesthesiology 2018; 128: 159-67.

27. Bamaga AK, Riazi S, Amburgey $K$, et al. Neuromuscular conditions associated with malignant hyperthermia in paediatric patients: a 25-year retrospective study. Neuromuscul Disord 2016; 26: 201-6.

28. O'Flynn RP, Shutack JG, Rosenberg H, Fletcher JE. Masseter muscle rigidity and malignant hyperthermia susceptibility in pediatric patients. An update on management and diagnosis. Anesthesiology 1994; 80: 1228-33 (free access).

29. Russell T, Riazi S, Kraeva N, Steel AC, Hawryluck LA. Ecstacyinduced delayed rhabdomyolysis and neuroleptic malignant syndrome in a patient with a novel variant in the ryanodine receptor type 1 gene. Anaesthesia 2012; 67: 1021-4 (free access).

30. Burkman JM, Posner KL, Domino KB. Analysis of the clinical variables associated with recrudescence after malignant hyperthermia reactions. Anesthesiology 2007; 106: 901-6 (free access).

31. Dobson G, Chong M, Chow L, et al. Guidelines to the practice of anesthesia - revised edition 2017. Can J Anesth 2017; 64: 65-91 (free access).

32. Barnes C, Stowell KM, Bulger T, Langton E, Pollock N. Safe duration of postoperative monitoring for malignant hyperthermia patients administered non-triggering anaesthesia: an update. Anaesth Intensive Care 2015; 43: 98-104 (free access). 